\title{
STUDI PENERIMAAN DAN PREFERENSI KONSUMEN TERHADAP MINYAK GORENG CURAH YANG DIFORTIFIKASI VITAMIN A
}

\author{
Study on Consumer Acceptance and Preference of Vitamin A-Fortified \\ Unbranded Palm Oil \\ DRAJAT MARTIANTO ${ }^{1}$, SRI ANNA MARLIYATI ${ }^{{ }^{*}}$, RETNANINGSIH $^{2}$, \\ HANDARU TRI MULYONO ${ }^{3}$ \\ ${ }^{1}$ Staf Pengajar Departemen Gizi Masyarakat, Fakultas Ekologi Manusia, Institut \\ Pertanian Bogor, Jalan Lingkar Kampus IPB Dramaga, Bogor 16680 \\ ${ }^{2}$ Staf Pengajar Departemen IImu Keluarga dan Konsumen, Fakultas Ekologi \\ Manusia, Institut Pertanian Bogor, Jalan Lingkar Kampus IPB Dramaga, \\ Bogor 16680 \\ ${ }^{3}$ Program Studi Gizi Masyarakat dan Sumberdaya Keluarga, Fakultas Pertanian, \\ Institut Pertanian Bogor, Kampus IPB Dramaga, Bogor 16680
}

\begin{abstract}
Vitamin A fortification in unbranded palm oil is an alternative solution to overcome Vitamin A deficiency problem. It, however, needs further study to determine consumer acceptance and preference of the Vitamin Afortified unbranded palm oil in order to make the fortified oil is acceptable and consumed by consumer. This study was divided into two steps, they are field study, held in Barrang Lompo Island - Makassar and Babakan Village - Bogor, and laboratory study, held in Organoleptic Laboratory and Food Processing Laboratory in Department of Community Nutrition, Bogor Agricultural University. Percentage of panelist assessment and non-parametric statistical test (KruskalWallis Test) was used to measure consumer acceptance and preference of fortified unbranded palm oil. The result of this study indicated that the color and aroma of fortified unbranded palm oil is accepted by the consumer. The color, aroma, and taste of food that processed with fortified unbranded palm oil were also accepted by the consumer. The complaint during the usage of fortified unbranded palm oil were mainly caused by the way consumer used and storing the sample. Thus, it can be concluded that there were no change between fortified unbranded palm oil characteristics, both used in a controlled circumstances (laboratory) and in an uncontrolled circumstances (household).
\end{abstract}

\section{Key words : consumer acceptance, unbranded palm oil, vitamin $A$ fortification}

\section{PENDAHULUAN}

Masalah Kekurangan Vitamin A (KVA) masih menjadi masalah gizi yang serius di dunia termasuk di Indonesia. Lebih dari $40 \%$ anak-anak di dunia menderita KVA (UNICEF dan MI 2004 dalam World Bank 2006). Menurut WHO (1991) dalam Almatsier (2002), diantara anak-anak prasekolah diperkirakan terdapat 6 sampai 7 juta kasus baru xerophthalmia terjadi tiap tahunnya. Sekitar 10,0\% penderita Xerophthalmia mengalami kerusakan kornea, dengan
$60 \%$ di antaranya hanya mampu bertahan hidup kurang dari satu tahun. Usahausaha untuk menanggulangi masalah KVA telah banyak dilakukan di antaranya dengan suplementasi serta fortifikasi Vitamin A pada produk pangan.

Hasil survei yang dilakukan oleh Martianto et al. (2005) menunjukkan bahwa sebesar $77,5 \%$ rumah tangga di Indonesia menggunakan minyak curah untuk menggoreng dan rata-rata konsumsi minyak goreng di Indonesia adalah sebesar 23 gram per hari. Menurut Amang et al. (1996), diperkirakan total 
konsumsi minyak goreng pada tahun 2013 di Indonesia adalah sebesar 2.533 juta liter minyak goreng. Untoro (2002) menyatakan bahwa minyak goreng merupakan salah satu bahan pangan yang banyak digunakan masyarakat dan berpeluang untuk difortifikasi.

Terdapat dua jenis minyak goreng yang beredar dipasaran, yaitu minyak goreng yang dijual dengan merek (brand) dan tidak bermerek (curah). Seiring dengan waktu khususnya di kalangan masyarakat ekonomi lemah, konsumsi minyak goreng di dunia cenderung meningkat (Sunaryo \& Wibowo 2002). Proporsi minyak goreng curah yang diproduksi dan diedarkan di Indonesia adalah sekitar $70-75 \%$ dari total produksi minyak goreng. Perbedaan harga yang cukup besar antara minyak goreng bermerek dan curah menjadi alasan utama mengapa minyak goreng curah lebih banyak dipilih untuk dikonsumsi (Martianto et al. 2005). Selain itu, minyak goreng curah merupakan medium yang baik bagi vitamin-vitamin larut lemak seperti Vitamin A. Beberapa pertimbangan tersebut menjadi dasar bagi pelaksanaan fortifikasi minyak goreng curah dengan Vitamin A.

Produk pangan yang telah difortifikasi, dalam hal ini adalah minyak goreng curah harus dapat diterima dan dimanfaatkan oleh konsumen sesuai dengan tujuan penggunaannya. Oleh sebab itu, perlu dilakukan penelitian untuk melihat sejauh mana penerimaan dan preferensi konsumen terhadap minyak goreng yang difortifikasi dengan Vitamin A. Tujuan penelitian ini adalah untuk mengkaji penerimaan dan preferensi konsumen terhadap minyak goreng curah yang difortifikasi Vitamin A pada kondisi sebelum digunakan dan setelah digunakan untuk menggoreng bahan makanan.

\section{METODE}

\section{Desain, Waktu, dan Tempat Penelitian Desain penelitian ini berupa penelitian survei dan penelitian} eksperimental. Penelitian ini merupakan bagian dari penelitian yang dilakukan atas kerjasama Koalisi Fortifikasi Indonesia (KFI) dengan Asian Development Bank (ADB). Penelitian ini terbagi menjadi dua yaitu penelitian lapang dan penelitian laboratorium. Penelitian lapang terdiri atas survei penerimaan konsumen terhadap minyak goreng curah yang difortifikasi Vitamin A dan uji penggunaan minyak goreng yang difortifikasi Vitamin $A$ di tingkat rumah tangga. Penelitian laboratorium dilakukan untuk menilai penerimaan konsumen terhadap sifat organoleptik minyak goreng curah yang difortifikasi Vitamin A.

Penelitian ini dilaksanakan pada bulan April - Juni 2008. Penelitian lapang dilakukan di Pulau Barrang Lompo, Makassar dan di Desa Babakan, Darmaga, Bogor. Penelitian laboratorium dilaksanakan di Laboratorium Penilaian Organoleptik, Departemen Gizi Masyarakat, Fakultas Ekologi Manusia, Institut Pertanian Bogor.

\section{Alat dan Bahan}

Alat yang digunakan pada penelitian ini adalah kuesioner uji organoleptik dan uji penggunaan di rumah, pengaduk (electric stirer), penggorengan, kompor, pisau, gelas, cawan, serta piring. Bahan yang digunakan dalam penelitian ini adalah minyak goreng curah, Vitamin A palmitat $1.000 .000 \mathrm{IU} / \mathrm{g}$.

\section{Tahapan}

Penelitian ini dilakukan dalam dua tahapan yaitu Tahap I Survei penerimaan konsumen serta Tahap II uji organoleptik dan uji penggunaan di rumah (home use test).

Tahap I: Survei Penerimaan Konsumen. Survei penerimaan konsumen terhadap minyak goreng curah yang difortifikasi Vitamin A dilakukan dengan wawancara dan pengamatan terhadap konsumen pada tingkat rumah tangga di Pulau Barrang Lompo Kabupaten Makassar. Jumlah responden yang diambil untuk survei penerimaan konsumen pada penelitian ini sebanyak 100 orang yang diperoleh melalui perhitungan seperti berikut ini. 


$$
\begin{aligned}
& n=\frac{n_{o}}{1+\frac{n_{o}-1}{N}} \quad ; \text { dengan } \\
& n_{o}=\frac{\bar{x} T^{2} t_{\frac{\alpha}{2}}(\alpha \beta)}{d^{2}}
\end{aligned}
$$

Keterangan:

$$
\begin{aligned}
& \mathrm{n}=\text { jumlah sampel minimum } \\
& t_{\frac{\alpha}{2}}(\alpha \beta)=1,96
\end{aligned}
$$

Data yang dikumpulkan merupakan data frekuensi dan jumlah pembelian minyak goreng curah, data penilaian konsumen terhadap fortifikasi Vitamin A pada minyak goreng dan data penerimaan konsumen terhadap minyak goreng yang difortifikasi Vitamin A.

Tahap II.a: Uji organoleptik di laboratorium. Jenis uji organoleptik yang digunakan yaitu uji kesukaan (hedonik). Sampel yang digunakan dalam uji organoleptik ini adalah minyak goreng curah yang difortifikasi Vitamin A dan minyak goreng curah yang tidak difortifikasi. Karakteristik organoleptik yang dinilai adalah warna dan aroma dari minyak goreng curah. Skala hedonik yang digunakan adalah (1) tidak suka, (2) kurang suka, (3) biasa, (4) agak suka, dan (5) suka. Penerimaan minyak goreng curah didapat dengan mengakumulasikan kesukaan responden terhadap minyak goreng curah. Pernyataan (3) biasa, (4) agak suka, dan (5) suka yang diberikan oleh responden menunjukkan bahwa produk yang diuji masih dapat diterima secara fisik dan cenderung sama dengan produk sejenis yang tersedia di pasaran. Responden pada uji ini adalah ibu rumah tangga yang berdomisili di Desa Babakan, Darmaga. Pelaksanaan pengujian dilakukan di Laboratorium Penilaian Organoleptik, Departemen Gizi Masyarakat. Jumlah responden pada uji kesukaan ini adalah sebanyak 28 orang.

Tahap II.b: Uji Penggunaan di Rumah (Home Use Test). Uji penggunaan di rumah (Home Use Test) dilakukan untuk menilai penerimaan konsumen terhadap minyak goreng yang dikonsumsi sesuai dengan tujuan penggunaan minyak goreng pada umumnya. Jenis uji yang dilakukan pada uji ini yaitu uji kesukaan terhadap warna dan aroma minyak goreng curah. Pemakaian kedua jenis minyak goreng curah yang diuji diserahkan sepenuhnya kepada responden. Selain itu responden juga diminta untuk menilai perbedaan warna dan aroma dari minyak goreng curah yang diujikan dengan minyak goreng curah yang biasa dipakai oleh responden.

Uji ini dilakukan di rumah masingmasing responden selama tujuh hari dan dilanjutkan dengan pengisian lembar penilaian untuk produk pertama yaitu minyak goreng curah yang tidak difortifikasi Vitamin A. Uji penggunaan di rumah terhadap produk kedua yaitu minyak goreng curah yang difortifikasi Vitamin A dilakukan setelah uji pada produk pertama selesai. Responden pada uji ini adalah ibu rumah tangga yang berdomisili di Desa Babakan, Darmaga. Jumlah responden pada uji kesukaan ini adalah sebanyak 28 orang.

\section{Pengolahan dan Analisis Data}

Data hasil survei penerimaan konsumen diolah secara deskriptif menggunakan persentase modus. Data yang diperoleh dari hasil uji kesukaan dan penerimaan konsumen terhadap minyak goreng yang difortifikasi Vitamin A diolah secara deskriptif menggunakan persentase kesukaan dan penerimaan responden serta skor modus masingmasing perlakuan. Uji statistik non parametrik Kruskal-Wallis digunakan untuk mengetahui perbedaan tingkat kesukaan responden terhadap sifat organoleptik minyak goreng curah. Datadata yang terkumpul dan telah diolah digunakan untuk membuktikan kekhawatiran-kekhawatiran mengenai perubahan sifat fisik minyak goreng curah jika difortifikasi dengan Vitamin A.

\section{HASIL DAN PEMBAHASAN}

\section{Penerimaan Konsumen terhadap Minyak Goreng Curah}

Penilaian konsumen tentang minyak goreng curah yang difortifikasi Vitamin A dibandingkan minyak goreng curah yang tidak difortifikasi Vitamin A disajikan pada Tabel 1. 
Warna. Lebih dari separuh jumlah responden $(53 \%)$ menilai warna minyak goreng curah yang difortifikasi Vitamin A sama saja dengan minyak goreng curah yang tidak difortifikasi (Tabel 1). Lima persen dari jumlah responden menilai warna minyak goreng curah yang difortifikasi Vitamin A lebih buruk dibanding minyak goreng curah yang tidak difortifikasi, sedangkan selebihnya responden menilai warna minyak goreng curah yang difortifikasi Vitamin A lebih baik dari minyak goreng curah yang tidak difortifikasi.

Aroma. Sebanyak $73 \%$ responden menyatakan aroma minyak goreng yang difortifikasi Vitamin A sama saja dengan aroma minyak goreng yang tidak difortifikasi Vitamin A (Tabel 1). Penurunan mutu minyak goreng seperti timbulnya bau tengik yang diakibatkan oleh terjadinya reaksi oksidasi lemak dan dapat pula menimbulkan rasa getir (Ketaren 1986) akan mempengaruhi penilaian konsumen terhadap minyak goreng.

Rasa Makanan. Berdasarkan Tabel 1, lebih dari separuh responden (65\%) menyatakan bahwa rasa makanan yang diolah menggunakan minyak goreng yang difortifikasi Vitamin A sama saja dengan rasa makanan yang diolah menggunakan minyak goreng curah yang tidak difortifikasi Vitamin A. Hanya 4\% dari jumlah responden yang menyatakan bahwa rasa makanan yang diolah menggunakan minyak goreng yang difortifikasi lebih buruk dibanding rasa makanan yang diolah menggunakan minyak goreng yang tidak difortifikasi.

Lebih dari separuh jumlah responden menyatakan bahwa warna dan aroma minyak goreng curah yang difortifikasi serta rasa makanan yang diolah adalah sama saja dibanding minyak goreng curah yang tidak difortifikasi. Secara keseluruhan, 58\% responden di Pulau Barrang Lompo menyatakan bahwa sifat organoleptik minyak goreng curah yang difortifikasi Vitamin A tidak berbeda atau sama saja dengan minyak goreng curah yang tidak difortifikasi, bahkan 33\% responden menyatakan lebih baik.

\section{Frekuensi Pembelian Minyak Goreng Curah}

Konsumsi seseorang atau suatu rumah tangga akan minyak goreng curah sangat beragam. Data frekuensi pembelian diperoleh dengan melakukan wawancara langsung kepada responden dan dengan melakukan pengkategorian frekuensi pembelian minyak goreng curah yang biasa dilakukan oleh responden. Frekuensi pembelian minyak goreng curah dapat dilihat pada Tabel 2 .

Tabel 1. Distribusi konsumen berdasarkan penilaian terhadap minyak goreng curah yang difortifikasi Vitamin A dibandingkan dengan minyak goreng curah yang tidak difortifikasi Vitamin A

\begin{tabular}{lcccc}
\hline \multirow{2}{*}{ Penilaian } & Warna & Aroma & $\begin{array}{c}\text { Rasa } \\
\text { Makanan }\end{array}$ & Keseluruhan \\
\cline { 2 - 5 } & 0,0 & 0,0 & 0,0 & 0,0 \\
\hline Jauh lebih buruk & 5,0 & 3,0 & 4,0 & 7,0 \\
Lebih buruk & 53,0 & 73,0 & 65,0 & 58,0 \\
Sama saja & 38,0 & 22,0 & 30,0 & 33,0 \\
Lebih baik & 4,0 & 1,0 & 1,0 & 1,0 \\
Jauh lebih baik & 0,0 & 1,0 & 0,0 & 1,0 \\
Tidak tahu & 100,0 & 100,0 & 100,0 & 100,0 \\
\hline \multicolumn{1}{c}{ Total } & & & & \\
\hline
\end{tabular}

Tabel 2. Frekuensi pembelian minyak goreng curah

\begin{tabular}{ccc}
\hline \multicolumn{1}{c}{ Frekuensi Pembelian } & Bogor (\%) & Barrang Lompo (\%) \\
\hline Beberapa kali dalam seminggu & 25,0 & 32,0 \\
Setiap seminggu sekali & 35,7 & 45,0 \\
Beberapa kali dalam sebulan & 39,3 & 23,0 \\
Tidak pernah membeli & 0,0 & 0,0 \\
\hline Total & 100,0 & 100,0 \\
\hline
\end{tabular}


Berdasarkan Tabel 2, frekuensi pembelian minyak goreng curah terbanyak di Bogor adalah membeli minyak goreng curah beberapa kali dalam sebulan $(39,3 \%)$, namun jumlah ini tidak berbeda jauh dengan $35,7 \%$ responden yang biasa membeli minyak goreng curah setiap seminggu sekali. Berbeda halnya dengan responden di Pulau Barrang Lompo, sebanyak $45 \%$ responden biasa membeli minyak goreng curah setiap seminggu sekali.

Selain frekuensi pembelian minyak goreng curah, jumlah minyak goreng curah yang dibeli pada setiap kali pembelian menggambarkan konsumsi minyak goreng curah di tingkat rumah tangga. Jumlah pembelian minyak goreng curah terkecil di kedua tempat adalah sebesar 0,25 kilogram pada setiap kali pembelian. Jumlah pembelian minyak goreng curah terbesar di Bogor hanya sebesar dua kilogram setiap kali pembelian. Berbeda dengan di Pulau Barrang Lompo yang mencapai sepuluh kilogram pada setiap kali pembelian.

\section{Ketertarikan Konsumen}

Fortifikasi Vitamin A menjadikan minyak goreng curah sebagai produk yang lebih tinggi nilai gizinya. Pelaksanaan fortifikasi berarti juga menambahkan satu proses pada rantai produksi minyak goreng. Hal ini akan berdampak terhadap peningkatan biaya produksi minyak goreng curah yang difortifikasi. Umumnya, peningkatan biaya produksi suatu produk akan berdampak pula terhadap peningkatan harga jual. Secara umum, kenaikan harga minyak goreng curah yang difortifikasi Vitamin A tidak terlalu mempengaruhi ketertarikan konsumen untuk membeli minyak goreng curah yang difortifikasi Vitamin $A$. Distribusi konsumen berdasarkan ketertarikan membeli minyak goreng curah jika terjadi kenaikan harga minyak goreng curah yang difortifikasi Vitamin A disajikan pada Tabel 3.

Persentase jumlah konsumen yang memutuskan tetap membeli minyak goreng curah yang difortifikasi Vitamin A pada angka kenaikan harga $\mathrm{Rp} 50,00$ dan Rp 100,00 per kilogramnya berturut-turut adalah $88 \%$ dan $86 \%$ (Tabel 3). Terjadi penurunan jumlah responden yang memilih membeli minyak goreng curah yang difortifikasi Vitamin $A$ seiring kenaikan harga minyak goreng tersebut. Berbeda halnya dengan jumlah responden yang memilih minyak goreng curah yang tidak difortifikasi Vitamin A meningkat seiring kenaikan harga minyak goreng curah yang difortifikasi Vitamin A. Hal serupa juga terjadi dengan jumlah responden yang tidak bisa memutuskan memilih jenis minyak goreng yang akan dikonsumsi dengan menjawab tidak tahu.

Tabel 3. Distribusi konsumen berdasarkan ketertarikan membeli minyak goreng curah jika terjadi kenaikan harga minyak goreng curah yang difortifikasi Vitamin A

\begin{tabular}{lcc}
\hline \multicolumn{1}{c}{$\begin{array}{c}\text { Ketertarikan } \\
\text { Konsumen }\end{array}$} & \multicolumn{2}{c}{$\begin{array}{c}\text { Persentase jumlah } \\
\text { konsumen (\%) }\end{array}$} \\
\cline { 2 - 3 } & $\begin{array}{c}\text { Naik Rp } \\
\mathbf{5 0 , 0 0}\end{array}$ & $\begin{array}{c}\text { Naik Rp } \\
\mathbf{1 0 0 , 0 0}\end{array}$ \\
\hline $\begin{array}{l}\text { Minyak yang } \\
\text { bervitamin A }\end{array}$ & 88,0 & 86,0 \\
Minyak yang tidak & 6,0 & 7,0 \\
bervitamin A & 2,0 & 2,0 \\
Sama saja & 4,0 & 5,0 \\
\hline Tidak tahu & 100,0 & 100,0 \\
\hline \multicolumn{1}{c}{ Total } & & \\
\hline
\end{tabular}

\section{Preferensi terhadap Minyak Goreng Curah yang Difortifikasi Vitamin A}

Preferensi terhadap minyak goreng curah yang difortifikasi Vitamin A diperoleh dengan melakukan uji kesukaan. Uji kesukaan (hedonik) dilakukan terhadap warna dan aroma minyak goreng curah yang difortifikasi Vitamin A serta minyak goreng curah yang tidak difortifikasi Vitamin A. Sebaran tingkat kesukaan responden terhadap warna minyak goreng curah yang difortifikasi dan tidak difortifikasi Vitamin A disajikan pada Tabel 4.

Tabel 4. Sebaran tingkat kesukaan responden terhadap warna minyak goreng curah

\begin{tabular}{lcc}
\hline $\begin{array}{c}\text { Tingkat } \\
\text { Kesukaan } \\
\text { terhadap } \\
\text { Warna }\end{array}$ & \multicolumn{2}{c}{$\begin{array}{c}\text { Persentase Tingkat } \\
\text { Kesukaan (\%) }\end{array}$} \\
\cline { 2 - 3 } & $\begin{array}{c}\text { Minyak } \\
\text { Fortifikasi }\end{array}$ & $\begin{array}{c}\text { Minyak } \\
\text { Non } \\
\text { Fortifikasi }\end{array}$ \\
\hline Tidak suka & 1,8 & 0,0 \\
Kurang suka & 8,9 & 1,8 \\
Biasa & 17,9 & 17,9 \\
Agak suka & 12,5 & 21,4 \\
Suka & 58,9 & 58,9 \\
\hline \multicolumn{1}{c}{ Total } & 100,0 & 100,0 \\
\hline
\end{tabular}


Berdasarkan Tabel 4, lebih dari separuh responden $(58,9 \%)$ menyatakan suka terhadap warna minyak goreng curah baik yang difortifikasi Vitamin A maupun minyak goreng curah yang tidak difortifikasi Vitamin A. Uji Kruskal-Wallis menunjukkan tidak ada perbedaan yang nyata antara kesukaan responden terhadap warna minyak goreng curah yang difortifikasi Vitamin A dan minyak goreng curah yang tidak difortifikasi Vitamin A $(p=0,586)$. Skor modus tingkat kesukaan warna minyak goreng curah yang difortifikasi Vitamin $A$ adalah 5 (suka) dengan persentase penerimaan sebesar $89,3 \%$.

Kesukaan responden terhadap aroma minyak goreng curah menentukan tingkat penerimaan aroma minyak goreng curah yang difortifikasi. Sebaran tingkat kesukaan responden terhadap aroma minyak goreng curah yang difortifikasi dan tidak difortifikasi Vitamin A disajikan pada Tabel 5.

Persentase tingkat kesukaan responden terhadap aroma minyak goreng curah tidak berbeda jauh untuk masing-masing skala kesukaan (Tabel 5). Kurang dari separuh responden $(44,6 \%)$ menyatakan suka terhadap aroma minyak goreng curah yang difortifikasi Vitamin A dan separuh dari jumlah total responden $(50 \%)$ menyatakan suka terhadap aroma minyak goreng curah yang tidak difortifikasi Vitamin A. Uji Kruskal-Wallis menunjukkan tidak ada perbedaan yang nyata $(p=0,586)$ antara kesukaan responden terhadap aroma minyak goreng curah yang difortifikasi Vitamin A dan minyak goreng curah yang tidak difortifikasi Vitamin A.

Tabel 5. Sebaran tingkat kesukaan responden terhadap aroma minyak goreng curah

\begin{tabular}{|c|c|c|}
\hline \multirow{2}{*}{$\begin{array}{l}\text { Tingkat } \\
\text { Kesukaan } \\
\text { terhadap } \\
\text { Aroma }\end{array}$} & \multicolumn{2}{|c|}{$\begin{array}{l}\text { Persentase Tingkat } \\
\text { Kesukaan }(\%)\end{array}$} \\
\hline & $\begin{array}{c}\text { Minyak } \\
\text { Fortifikasi }\end{array}$ & $\begin{array}{c}\text { Minyak Non } \\
\text { Fortifikasi }\end{array}$ \\
\hline Tidak suka & 1,8 & 0,0 \\
\hline Kurang suka & 8,9 & 7,2 \\
\hline Biasa & 32,2 & 33,9 \\
\hline Agak suka & 12,5 & 8,9 \\
\hline Suka & 44,6 & 50,0 \\
\hline Total & 100,0 & 100,0 \\
\hline
\end{tabular}

Aroma yang khas pada minyak kelapa sawit ataupun minyak goreng curah disebabkan oleh senyawa $\beta$-ionone yang terkandung didalamnya (Ketaren 1986). Sebagian besar responden $(89,3 \%)$ dapat menerima aroma yang timbul dari minyak goreng curah yang dfortifikasi Vitamin A, dengan skor modus 5 (suka). Hal ini menunjukkan bahwa aroma minyak goreng curah yang difortifikasi dapat diterima oleh konsumen.

\section{Uji Kesukaan Minyak Goreng Curah di Rumah Tangga}

Responden diminta untuk memberikan penilaian mengenai kesukaan terhadap minyak yang diuji setelah digunakan dalam beberapa kali penggorengan. Ulangan pemakaian minyak goreng curah yang diuji secara organoleptik adalah setelah satu kali pemakaian, dua kali pemakaian dan tiga kali pemakaian. Menurut Pantzaris (1999), minyak goreng terutama yang digunakan pada proses penggorengan deep frying sering kali digunakan terus menerus sehingga terjadi degradasi yang sangat intensif. Lemak yang terkandung dalam pangan yang digoreng pun ikut mengalami oksidasi, walaupun tidak terekspos dalam waktu lama dan hanya pada bagian permukaanya saja. Perubahan-perubahan yang terjadi karena proses oksidasi tergantung pada kandungan asam lemak tak jenuh ganda pada minyak.

Pemakaian Pertama. Pemakaian minyak goreng curah yang diujikan diserahkan sepenuhnya kepada responden. Hasil uji kesukaan berupa skor modus dan persentase penerimaan terhadap minyak goreng curah pemakaian pertama disajikan pada Tabel 6.

Warna. Berdasarkan Tabel 6, skor modus tingkat kesukaan warna pada minyak goreng curah yang diujikan adalah agak suka (4) dan biasa (3). Persentase penerimaan responden terhadap warna minyak goreng curah yang difortifikasi Vitamin A pada pemakaian pertama lebih rendah jika dibandingkan dengan persentase penerimaan terhadap warna minyak goreng curah yang tidak difortifikasi. Uji Kruskal-Wallis menunjukkan tingkat kesukaan responden terhadap warna kedua jenis minyak goreng curah yang diujikan tidak berbeda nyata $(p=0,292)$. Hal ini menunjukkan bahwa warna minyak goreng curah yang difortifikasi Vitamin A 
setelah satu kali penggunaan dapat diterima oleh konsumen.

Aroma. Persentase penerimaan responden terhadap aroma minyak goreng curah yang difortifikasi Vitamin A (96,4\%) sebanding dengan persentase penerimaan responden terhadap aroma minyak goreng yang tidak difortifikasi sebesar 92,9\% (Tabel 6). Skor modus tingkat kesukaan aroma minyak goreng curah yang difortifikasi Vitamin A adalah agak suka (4), sedangkan pada minyak goreng yang tidak difortifikasi adalah suka (5). Uji Kruskal-Wallis menunjukkan tidak ada perbedaan yang nyata $(p=0,104)$ tingkat kesukaan responden terhadap aroma kedua jenis minyak goreng curah yang diujikan. Hal ini menunjukkan bahwa aroma minyak goreng curah yang difortifikasi Vitamin A setelah satu kali penggunaan dapat diterima oleh konsumen.

Rasa Makanan. Berdasarkan Tabel 6 , skor modus tingkat kesukaan terhadap rasa makanan yang diolah menggunakan minyak goreng curah yang difortifikasi Vitamin A adalah biasa (3), sedangkan pada minyak goreng yang tidak difortifikasi adalah suka (5). Persentase penerimaan responden terhadap rasa makanan yang diolah menggunakan minyak goreng curah yang difortifikasi Vitamin A lebih tinggi dibandingkan dengan persentase penerimaan responden terhadap rasa makanan yang diolah menggunakan minyak goreng yang tidak difortifikasi. Uji Kruskal-Wallis menunjukkan adanya perbedaan yang nyata $(p=0,010)$ tingkat kesukaan responden terhadap rasa makanan yang diolah menggunakan minyak goreng curah yang diuji. Meski dengan skor modus yang lebih rendah, data persentase penerimaan menunjukkan bahwa rasa makanan yang diolah pada pemakaian pertama minyak goreng curah yang difortifikasi Vitamin A dapat diterima oleh konsumen.

Pemakaian Kedua. Umumnya konsumen menggunakan minyak goreng untuk mengoreng bahan makanan tidak sekali pakai tetapi masih digunakan hingga pemakaian kedua ketiga, dan seterusnya selama penampakan atau sifat organoleptik (warna, aroma dan rasa) minyak goreng masih dianggap baik. Hasil uji kesukaan berupa skor modus dan persentase penerimaan terhadap minyak goreng curah pemakaian kedua disajikan pada Tabel 7 .

Warna. Berdasarkan Tabel 7, persentase penerimaan responden terhadap warna minyak goreng curah yang difortifikasi Vitamin A lebih rendah dibanding minyak goreng yang tidak difortifikasi. Skor modus tingkat kesukaan warna pada minyak goreng curah yang diujikan adalah agak suka (4). Uji KruskalWallis menunjukkan tidak ada perbedaan yang nyata $(p=0,063)$ tingkat kesukaan responden terhadap warna kedua jenis minyak goreng curah yang diujikan. Hal ini menunjukkan bahwa warna minyak goreng curah yang difortifikasi Vitamin A setelah pemakaian kedua dapat diterima oleh konsumen.

Tabel 6. Hasil uji kesukaan berupa skor modus dan persentase penerimaan responden terhadap minyak goreng curah pemakaian pertama

\begin{tabular}{lrcrrr}
\hline \multirow{2}{*}{ Parameter Uji } & \multirow{2}{*}{ Nilai p } \\
\cline { 2 - 5 } & \multicolumn{2}{c}{ Fortifikasi } & \multicolumn{2}{c}{ Non Fortifikasi } & (a = 0,05) \\
\cline { 2 - 5 } & Modus & Penerimaan (\%) & Modus & Penerimaan (\%) & \\
\hline Warna & 3 dan 4 & 89,3 & 3 dan 4 & 100,0 & 0,292 \\
Aroma & 4 & 96,4 & 5 & 92,9 & 0,104 \\
Rasa Makanan & 3 & 96,4 & 5 & 92,9 & 0,010 \\
\hline
\end{tabular}

Tabel 7. Hasil uji kesukaan berupa skor modus dan persentase penerimaan responden terhadap minyak goreng curah pemakaian kedua

\begin{tabular}{lccrrr}
\hline \multirow{2}{*}{ Parameter Uji } & \multirow{2}{*}{ Nilai p } \\
\cline { 2 - 5 } & \multicolumn{3}{c}{ Fortifikasi } & Nonis Minyak & Non Fortifikasi \\
\cline { 2 - 5 } & Modus & Penerimaan (\%) & Modus & Penerimaan (\%) \\
\hline Warna & 4 & 89,3 & 4 & 100,0 & 0,063 \\
Aroma & 4 & 92,9 & 4 dan 5 & 92,9 & 0,026 \\
Rasa Makanan & 3 & 92,9 & 4 & 92,9 & 0,013 \\
\hline
\end{tabular}


Aroma. Persentase penerimaan responden terhadap aroma minyak goreng curah yang difortifikasi Vitamin A sama dengan persentase penerimaan terhadap aroma minyak goreng yang tidak difortifikasi. Skor modus tingkat kesukaan terhadap aroma minyak goreng curah yang difortifikasi Vitamin A adalah agak suka (4), sedangkan pada minyak goreng yang tidak difortifikasi adalah suka (5) dan agak suka (4). Uji Kruskal-Wallis menunjukkan adanya perbedaan yang nyata $(p=0,026)$ tingkat kesukaan responden terhadap aroma kedua jenis minyak goreng curah yang diuji. Persentase penerimaan dan skor modus menunjukkan bahwa aroma minyak goreng curah yang difortifikasi Vitamin A setelah pemakaian kedua dapat diterima oleh konsumen.

Rasa Makanan. Tabel 7 menunjukkan bahwa skor modus tingkat kesukaan rasa makanan yang diolah menggunakan minyak goreng curah yang difortifikasi Vitamin A adalah biasa (3), sedangkan pada minyak goreng yang tidak difortifikasi adalah agak suka (4). Persentase penerimaan responden terhadap rasa makanan yang diolah menggunakan minyak goreng curah yang difortifikasi Vitamin A pada pemakaian kedua sama dengan persentase penerimaan rasa makanan yang diolah menggunakan minyak goreng curah yang tidak difortifikasi. Uji Kruskal-Wallis menunjukkan adanya perbedaan yang nyata $(p=0,013)$ tingkat kesukaan responden terhadap rasa makanan yang diolah menggunakan minyak goreng curah yang diujikan. Meskipun dengan skor modus yang lebih rendah, persentase penerimaan menunjukkan bahwa rasa makanan yang diolah pada pemakaian kedua minyak goreng curah yang difortifikasi Vitamin A dapat diterima oleh konsumen.

Pemakaian Ketiga. Setelah dua kali digunakan untuk menggoreng, responden menyatakan bahwa minyak yang diujikan masih memiliki penampakan yang baik, namun hal ini tentu saja bergantung pada jenis bahan makanan yang digoreng serta cara masing-masing responden dalam menggoreng. Hasil uji kesukaan berupa skor modus dan persentase penerimaan responden terhadap minyak goreng curah pemakaian ketiga disajikan pada Tabel 8.

Warna. Berdasarkan Tabel 8, skor modus tingkat kesukaan aroma minyak goreng curah yang difortifikasi Vitamin A adalah agak suka (4), sedangkan pada minyak goreng yang tidak difortifikasi adalah suka (5). Persentase penerimaan responden terhadap warna minyak goreng curah yang difortifikasi Vitamin A setelah tiga kali pemakaian lebih rendah jika dibandingkan terhadap persentase penerimaan responden terhadap warna minyak goreng curah yang tidak difortifikasi. Uji Kruskal-Wallis menunjukkan adanya perbedaan yang nyata $(p=0,045)$ tingkat kesukaan responden terhadap warna kedua jenis minyak goreng curah yang diujikan. Meski dengan skor modus dan persentase penerimaan yang lebih rendah, warna minyak goreng curah yang difortifikasi Vitamin A setelah tiga kali penggunaan dapat diterima oleh konsumen.

Aroma. Berdasarkan Tabel 8, skor modus tingkat kesukaan aroma minyak goreng curah yang difortifikasi Vitamin A adalah agak suka (4), sedangkan pada minyak goreng yang tidak difortifikasi adalah suka (5). Persentase penerimaan responden terhadap aroma minyak goreng curah yang difortifikasi Vitamin A setelah tiga kali pemakaian lebih rendah jika dibandingkan terhadap persentase penerimaan responden terhadap aroma minyak goreng curah yang tidak difortifikasi. Uji Kruskal-Wallis menunjukkan adanya perbedaan yang nyata $(p=0,027)$ tingkat kesukaan responden terhadap aroma kedua jenis minyak goreng curah yang diujikan. Aroma

Tabel 8. Hasil uji kesukaan berupa skor modus dan persentase penerimaan responden terhadap minyak goreng curah pemakaian ketiga

\begin{tabular}{|c|c|c|c|c|c|}
\hline \multirow{3}{*}{ Parameter Uji } & \multicolumn{4}{|c|}{ Jenis Minyak } & \multirow{3}{*}{$\begin{array}{c}\text { Nilai } p \\
(\alpha=0,05)\end{array}$} \\
\hline & \multicolumn{2}{|c|}{ Fortifikasi } & \multicolumn{2}{|c|}{ Non Fortifikasi } & \\
\hline & Modus & Penerimaan (\%) & Modus & Penerimaan (\%) & \\
\hline Warna & 4 & 71,4 & 5 & 82,1 & 0,045 \\
\hline Aroma & 4 & 75,0 & 5 & 92,9 & 0,027 \\
\hline Rasa Makanan & 4 & 71,4 & 5 & 92,9 & 0,026 \\
\hline
\end{tabular}


minyak goreng curah yang difortifikasi Vitamin A setelah tiga kali penggunaan dapat diterima oleh konsumen meskipun dengan skor modus dan persentase penerimaan yang lebih rendah dibanding minyak goreng yang tidak difortifikasi.

Rasa Makanan. Berdasarkan Tabel 8, skor modus tingkat kesukaan rasa makanan yang diolah menggunakan minyak goreng curah yang difortifikasi $A$ adalah agak suka (4), sedangkan pada minyak goreng yang tidak difortifikasi adalah suka (5). Persentase penerimaan responden terhadap rasa makanan yang diolah menggunakan minyak goreng curah yang difortifikasi Vitamin A pada pemakaian ketiga lebih rendah jika dibandingkan dengan persentase penerimaan responden terhadap rasa makanan yang diolah menggunakan minyak goreng curah yang tidak difortifikasi. Uji Kruskal-Wallis menunjukkan adanya perbedaan yang nyata $(p=0,026)$ tingkat kesukaan responden terhadap aroma kedua jenis minyak goreng curah yang diujikan. Meskipun dengan skor modus dan persentase penerimaan yang lebih rendah, rasa makanan yang diolah menggunakan minyak goreng curah yang difortifikasi Vitamin A setelah tiga kali penggunaan dapat diterima oleh konsumen.

Minyak goreng yang difortifikasi Vitamin A dapat diterima secara organoleptik oleh konsumen, namun beberapa responden menyampaikan keluhan mengenai pemakaian minyak goreng curah yang difortifikasi Vitamin A. Keluhan-keluhan mengenai minyak goreng curah yang difortifikasi Vitamin A dapat dilihat pada Tabel 9.

Berdasarkan Tabel 9, keluhan terbanyak $(32,1 \%)$ yang disampaikan oleh responden mengenai minyak goreng yang difortifikasi Vitamin A yaitu minyak goreng cepat habis atau meresap ke dalam makanan pada saat digunakan menggoreng. Keluhan lainnya yang muncul adalah minyak goreng yang difortifikasi Vitamin A lebih cepat mengendap setelah disimpan. Hal ini dikeluhkan oleh 10,7\% dari jumlah responden pada uji penggunaan minyak di rumah tangga.
Tabel 9. Keluhan mengenai minyak goreng curah yang difortifikasi Vitamin A

\begin{tabular}{lcc}
\hline \multicolumn{1}{c}{ Keluhan } & \multicolumn{2}{c}{ Persentase (\%) } \\
\cline { 2 - 3 } & Fortifikasi & $\begin{array}{c}\text { Non } \\
\text { Fortifikasi }\end{array}$ \\
\hline $\begin{array}{l}\text { Minyak goreng cepat } \\
\text { habis (menyerap ke } \\
\text { makanan) }\end{array}$ & 32,1 & 10,7 \\
$\begin{array}{l}\text { Minyak goreng } \\
\text { berbuih saat dipakai } \\
\text { Minyak goreng cepat }\end{array}$ & 17,9 & 10,7 \\
$\begin{array}{l}\text { rusak (berwarna } \\
\text { hitam) }\end{array}$ & 21,4 & 3,6 \\
$\begin{array}{l}\text { Minyak goreng cepat } \\
\text { mengendap setelah } \\
\text { disimpan }\end{array}$ & 10,7 & 0,0 \\
\hline
\end{tabular}

Jumlah keluhan mengenai minyak goreng curah yang tidak difortifikasi Vitamin A lebih rendah dibanding jumlah keluhan mengenai minyak goreng curah yang difortifikasi Vitamin A. Keluhan yang terjadi sangat tergantung pada jenis makanan yang diolah serta kondisi tempat penyimpanan minyak yang diujikan. Pengendapan yang terjadi pada minyak goreng tergantung pada jenis minyak goreng itu sendiri. Tahapan pada saat pembuatan minyak goreng berpengaruh terhadap sifat fisik dan kimia minyak goreng.

\section{KESIMPULAN DAN SARAN}

\section{Kesimpulan}

Sebagian besar responden menyatakan bahwa warna dan aroma minyak goreng curah yang difortifikasi Vitamin A sama dengan minyak goreng curah yang tidak difortifikasi Vitamin A. Di samping itu, preferensi responden terhadap warna dan aroma minyak goreng curah yang difortifikasi Vitamin A sama dengan minyak goreng curah yang tidak difortifikasi Vitamin A. Dalam hal penerimaan responden terhadap warna dan aroma, minyak goreng curah yang difortifikasi Vitamin A masih dapat diterima responden setelah dua kali penggunaan. Demikian pula setelah tiga kali penggunaan, meskipun dengan skor modus dan persentase penerimaan yang lebih rendah dibanding minyak goreng yang tidak difortifikasi. 
Saran

Minyak goreng yang dipakai beruang-ulang dan terus-menerus dapat menyebabkan kerusakan pada minyak goreng itu sendiri. Oleh karena itu, minyak goreng curah baik yang difortifikasi Vitamin A maupun yang tidak sebaiknya hanya digunakan untuk tiga kali penggorengan. Namun, minyak goreng yang digunakan untuk bahan pangan yang diolah dengan bermacammacam bumbu serta memiliki kandungan gizi yang tinggi sebaiknya hanya digunakan sebanyak satu kali saja.

\section{UCAPAN TERIMA KASIH}

Ucapan terima kasih disampaikan kepada KFI (Koalisi Fortifikasi Indonesia), Depkes RI dan ADB (Asian Development Bank) atas dukungan dana yang diberikan pada penelitian ini.

\section{DAFTAR PUSTAKA}

Almatsier S. 2002. Prinsip Dasar IImu Gizi. Jakarta: Gramedia Pustaka Utama.

Amang B, Simatupang $P$, Syafa'at N. 1996. Ekonomi Minyak Goreng [abstrak]. Di dalam: Amang B et al., editor. Ekonomi Minyak Goreng di Indonesia. Bogor: IPB Press.

\footnotetext{
*Korespondensi :

Departemen Gizi Masyarakat Fakutas Ekologi Manusia IPB Jl. Lingkar Kampus IPB Dramaga 16680 Telp : +62-2518628303

Email : anna_marliyati@yahoo.com
}

Ketaren S. 1986. Pengantar Teknologi Minyak dan Lemak Pangan. Jakarta: UI Press.

Martianto et al. 2005. Possibility of Vitamin A Fortification on Cooking Oil in Indonesia: A Feasibility Analysis. Koalisi Fortifikasi Indonesia.

Pantzaris TP. 1999. Palm Oil in Frying. Di dalam: Dimitrios B, Ibrahim E, editor. Frying of Food. USA: CRC Press.

Sunaryo ES dan Wibowo A. 2002. Peluang dan Tantangan Fortifikasi Vitamin A pada Minyak Goreng. Di dalam: Hardinsyah et al., editor. Fortifikasi Tepung Terigu dan Minyak Goreng. Pusat Studi Kebijakan Pangan dan Gizi IPB. Komisi Fortifikasi Nasional. ADB-Manila dan Keystone Center USA.

Untoro R. 2002. Masalah Gizi Mikro di Indonesia dan Potensi Penanggulangannya. Di dalam: Hardinsyah et al., editor. Fortifikasi Tepung Terigu dan Minyak Goreng. Pusat Studi Kebijakan Pangan dan Gizi IPB. Komisi Fortifikasi Nasional. ADB-Manila dan Keystone Center USA.

World Bank. 2006. Repositioning Nutrition as Central to Development : $A$ Strategy for Large-Scale Action. Washington: World Bank. 